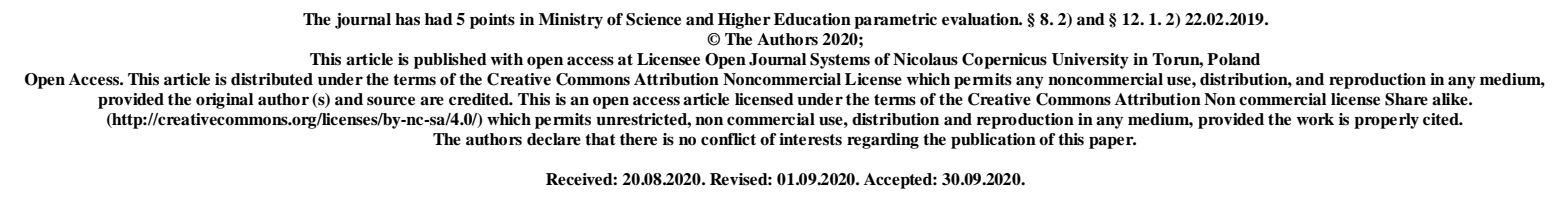

UDC 371.212 .3

\title{
FACILITATION QUALITIES OF THE FUTURE TEACHER
}

\section{Iryna Prokopenko}

\section{H. S. Skovoroda Kharkiv National Pedagogical University, Ukraine}

training.center.hnpu@gmail.com

\section{Abstract}

The realities of today require active, creative future professionals who are trained in pedagogical universities. Therefore, in order to intensify the educational activities of students, special attention should be paid to the organization of facilitation interaction in the following dyads: "teacher-group", "teacher-student", "student-group", "student-student". Currently, insufficient attention is paid to the problem of facilitation interaction between teachers and students. If in the traditional conditions the organization of the educational process is possible on the basis of facilitation interaction, then in the conditions of the pandemic (COVID-19) teachers and students had to face unexpected difficulties due to the introduction of selfisolation. The author proved that if the system of higher education still functioned quite effectively online, the school education system was not ready for self-isolation. In Ukraine, by March 2020, less than 1\% of students studied remotely. It should be noted that the closure of general secondary education and the emergency transition to distance learning are associated with obvious problems, mainly due to insufficient technical equipment, lack or insufficient training of both teachers and students to work in a pandemic. The author raises the problem that the organization of facilitation interaction of teachers with students requires the formation of the teacher's facilitation qualities. 
Keywords: pedagogical university; future teacher; student; facilitation interaction; facilitation qualitiesl; educational process.

\section{Introduction}

Ukraine's integration into the European educational space necessitated the modernization of the system of professional training, which primarily affected the quality standards of higher education, which are based on leading competencies, personal and professional qualities of teachers as a subject of pedagogical activity. Modern pedagogical education is gradually reoriented from a cognitively oriented model of training to a personality-oriented, built on the principles of facilitation interaction, cooperation, partnership of all participants in the educational process.

The urgency of the problem is substantiated in a number of normative documents (National Strategy for Education Development in Ukraine until 2021 (2013), The concept of implementation of state policy in the field of reforming general secondary education "New Ukrainian School" for the period up to 2029 (2016), a completely new order of the Ministry of Education and Science №1431 on conducting an all-Ukrainian experiment on "Organizational and pedagogical conditions for soft students skills through socio-emotional and ethical learning "on the basis of general secondary education institutions of Ukraine until 2024 (2019)) and fundamental domestic and foreign research on the general theoretical foundations of the problem of preparing future teachers for facilitation interaction.

Noting the focus of modern tasks of professional training of future teachers on the formation of a new style of pedagogical thinking, professional self-awareness and humanistic position, scientists point out that this problem is complicated by the fact that the personality of a traditional school teacher is usually characterized by inertia. in behavior, in particular, the role of authoritarian mentor.

\section{Analysis of scientific research}

Determining the degree of elaboration of this problem, first of all we note that aspects of general pedagogical training of teachers, his professional development are revealed in the fundamental works of V. Andrushchenko, O. Antonova, V. Bondar, O. Vozniuk, O. Dubasenyuk, S. Zolotukhina, I. Zyazyun, L. Kondrashova, N. Kuzmina, O. Pekhota, S. Sysoeva, V. Semichenko, O. Sukhomlynska and others.

Researchers' research allows to state that the pedagogical context of teacher facilitation as a specific type of professional pedagogical activity is revealed in the scientific achievements of modern scientists-teachers in the following areas: principles of facilitation 
(I. Avdeeva, O. Shakhmatova), facilitative skills (I. Lytvyn, P. Lushin), facilitative approach (G. Voloshko), facilitative communication (V. Vrublevskaya, S. Kolomiychenko), teacher training (R. Dimukhametov, S. Stepanov), pedagogical technology (O. Levchenko, A. Martynova, O. Romanyshyna , O. Fisun and others). An important place is given to facilitation in foreign psychological and pedagogical research (R. Bostrom, B. Broome, D. Keever, S. Ghais, L. Hart, D. Hunter, B. Taylor. J. Jenkins, A. Kiser, K. Winterburn).

The purpose of the article is to determine the factors that will contribute to the formation of facilitation qualities in future teachers

\section{Presenting main material}

The presence of professionally important qualities enriches the personality, expands its capabilities in all spheres of life. But at the same time it is necessary to establish what determines the possibility of achieving a high level of professionalism and is the basis for the formation of teachers of professionally significant qualities for teachers.

The teacher's personality is considered not only as a carrier of knowledge, ethical norms, traditions, but also as a carrier of certain individual characteristics, capable of improvement in the educational process.

The task of the teacher is to be a moderator, organizer of the educational process and the formation of the future teacher's personality, to show an emotional example, to inspire others with their interest, joint activities. Therefore, there is a need to focus on the training of future teachers in the pedagogical universities on the formation of professionally significant personality traits of the applicant, without which the process of organizing the educational activities of high quality professionals is impossible, in particular to professional activities school. In the process of professional training it is expedient to prepare the student to understand that his future professional activity, in relation to the principle of democratization of education, puts forward requirements to his communicative culture, perceptual and suggestive abilities, to his reflexological ability. In the process of preparation the future teacher must understand that his daily professional activity will have the character that he will have to see and understand the individuality of each student, pedagogically and psychologically adequately respond to his personal manifestations, create a favorable atmosphere for his creative activity. These qualities of the teacher develop, first of all, in the process of constant involvement of the student in the corresponding educational activity.

Therefore, the primary task of a teacher at a pedagogical university is to systematically assist future teachers in the future understanding of various, especially contradictory phenomena of the modern school educational environment and society. In the conditions of 
deep and comprehensive social transformations, a large number of contradictory phenomena, the student especially needs a positive influence of the authority of teachers, imitation of their personal qualities.

The educational process should promote a high level of readiness of the future teacher to develop his professionally necessary qualities and traits of the psyche, qualities and psychological and pedagogical characteristics relevant to the chosen profession.

Domestic psychological and pedagogical science traditionally identifies four main styles of pedagogical interaction: authoritarian, democratic and liberal and pedagogical. Within the framework of the scientific discussion, another classification of styles of pedagogical interaction is proposed, which is based on the analysis of psychological mechanisms that determine the communicative strategy of the individual. This classification allows us to distinguish three fundamentally different in their psychological nature of style: authoritarian, manipulative and dialogical. For full, comprehensive and effective disclosure of the content of interaction styles and forms, it is necessary to choose several criteria: understanding or misunderstanding of other participants in the interaction of the specifics of organized adult learning; development that participants of pedagogical interaction receive (or do not receive).

Authoritarian style of interaction is manifested in the centralization of the entire educational process on the individual. Authoritarianism is manifested in the reduction of selfanalysis and self-control of the teacher and significantly hinders the development of independence and activity of students. Authoritarian style of communication, according to researchers, generates inadequate self-esteem of students, instills a cult of strength, forms neurotics, causes an inadequate level of demands in the process of interaction with others [14]. It should also be noted that the psychological nature of the authoritarian style of pedagogical interaction includes unconscious psychological defenses, hiding deep distrust of oneself, one's own abilities and capabilities in both personal and professional growth ("professional burnout").

Liberal style of interaction in most cases is perceived as a negative phenomenon. It is described as follows: pedagogical interaction is characterized by a tendency of the teacher's desire to be less involved in the work in the classroom. Such teachers only formally perform their direct duties, limiting themselves exclusively to teaching. The result of the chosen strategy is the lack of control over the activities of students and the dynamics of the formation of their personality. Usually, success in groups of liberal teachers is unsatisfactory. Inconsistency in decisions and actions, indecision in difficult situations is characteristic of a 
liberal teacher. However, there is another opinion in the scientific community about this. Liberal (from the Latin. Liberalis - free possession) means "gives priority to freedom", which recognizes human freedom as a key value. Freedom is the main thing that distinguishes man from everything inhuman. According to existential philosophy, the meaning of freedom is that man is not an object formed under the influence of society, just as he is not a "product" of genetic origin, but chooses himself, creates his personality by his own actions and deeds in each moment of his life. Thus, man is free in the creation of his own life, is fully responsible for everything done in it.

Democratic style of interaction is characterized by close ties with students, through trust and respect for them, the teacher tries to normalize and strengthen emotional contact with the group without suppressing them. In his pedagogical activity, a teacher who adheres to a democratic style of interaction, activates intellectual enthusiasm and motivation for cognitive activity. If the student feels tension, negativity in his direction from the teacher, indifference to their own experiences, misunderstandings, he has a negative attitude towards the teacher. This creates aggression and contradictions in the organization of interaction between adult education.

A friendly, trusting attitude promotes learning, increases self-confidence and motivates students to actively acquire new knowledge, skills and abilities. It is believed that fundamentally changes the essence of the democratic style of interaction and illustrates it as a misnamed style of communication.

Manipulative style of interaction in the organization of students is manifested in the latent centralization of the educational process, that is, the teacher-manipulator does not impose on students their goals and values, he tries to make those in the learning process independently take them as their own. The manipulator is a psychologically literate authoritarian who understands that authoritarianism is not beneficial to himself and, using more subtle techniques to control the behavior of students, he can achieve significant success in their professional activities [10]. The difference between authoritarian and manipulative interaction is that in the first case, the focus on "communicative dictation" has a clear form, in the organization of manipulative interaction - hidden. The most important task for the manipulator is to understand the needs, interests, and "vulnerabilities" of the objects of manipulation and capture them in the field of influence. Obviously, the assessment system that exists in modern adult education is not so much focused on acquiring information about a certain level of knowledge of students, as on the management of their consciousness and behavior. 
Dialogic style of interaction - a style of communication based on dialogue. Dialogue is often mistaken for communication between two people, confusing the prefixes "di" (two, double) and "dia" (through). In the correct sense, dialogue is interpreted as symmetrical, equivalent interpersonal relationships that give everyone the right to be understood and understood by others; the right to mutual understanding and mutual respect [1].

The dialogic style of pedagogical interaction is manifested in the desire of all participants in the educational process to build communication on the principles of parity, mutual understanding, co-creation and cooperation. Dialogue not only acts as a means of communication, but is also one of the basic conditions of self-actualization and personal growth [9, p. 103]. Dialogic style is characterized by a focus on understanding the other. But in contrast to manipulative interaction, where the problem of understanding other participants is also important, the dialogic communicative space is based on mutual understanding. It should be noted that the dialogic style creates the most optimal opportunities for full development and personal growth of all participants in the educational process. The professional position of teachers, building their activities on dialogue, is based on the recognition of students as equal participants in pedagogical interaction and responsible subjects of free personal self-determination and self-actualization. Such teachers do not see their mission in fulfilling the roles of a repeater of standardized educational content, a supervisor and a controller, etc., inherent in the traditional teaching system. Such teachers are defined by psychological science as professional facilitators (from the English. Facilitate - to help, assist) - one who contributes to the personal development of the individual, helps him in finding and creating favorable conditions for self-actualization $[4 ; 11]$.

The pedagogical style of pedagogical interaction is unacceptable, although it is very often used by teachers. Such a teacher is not responsible for his pedagogical actions, he destroys the psyche of students, promotes neurosis, and develops a complex of inferiority [7].

Based on the analysis, it should be noted that the mutual understanding of the teacher with his students and the formation of the teacher's facilitative qualities largely depends on the style of pedagogical interaction.

The success of the organization of the educational process depends on the development of facilitation qualities, which is a component of personal. It is clear that we are talking about professionally important personality traits, the formation of which is based on the restructuring of certain personal qualities in accordance with the characteristics of professional activity, as well as the general logic of restructuring, restructuring qualities in 
accordance with professional activities, the emergence and development of new qualities formation of individual style of activity.

Let's try to formulate the principles of formation of facilitative qualities of personality:

1) each stage of training forms certain facilitation qualities, which is due to the level of acquired knowledge;

2) sequences: the initial, elementary qualities, formed at one stage, become the basis for the formation of more complex qualities;

3 ) integrativeness: the need to combine the capabilities of subjects and all elements of the pedagogical process in order to form the facilitation qualities of the future teacher;

4) practical orientation: the participation of students in a variety of creative activities that contribute to the formation of facilitation qualities.

At the first stage, special attention should be paid to the development of the ability to plan their work, to find rational means of solving a problem or task, the ability to control the performance of the task. Already at the first stages, such indicators of business quality are formed as: diligence, accuracy, responsibility, diligence.

Emotionality and the desire for knowledge helps teachers to involve students in creative pursuits, stimulate creative activity in the process of learning interaction in dyads "teacher - student", "student - student", "teacher - group", which promotes imagination, imagination, helps to notice and highlight the main, essential during communication, motivates the desire to find their purpose in life.

At the last stage there is an ethical-psychological and practical preparation of students for vital, social and professional self-determination on the basis of diagnostics of professional and moral-ethical qualities formed at the previous stages of the educational process. You can try to separate the ability to pedagogical or other activities. At this stage, the main direction of work is the formation of personally and socially valuable motivation to choose a further field of activity.

The formation of priority for the selected area of facilitation qualities should meet the interests and needs of students.

It should be noted that the development of personal and ethical potential is impossible without the formation of ethics of interpersonal interaction, because in modern society the range of interpersonal interaction is significantly expanding; graduates must be able to establish contacts with the employer, partners and colleagues immediately after graduation. The effectiveness of achieving the set goal depends on how professionally and correctly they will follow the rules of communication. 
Therefore, at all stages of teaching it is important for teachers to gradually provide students with tasks that would be similar in content to various aspects of teaching. Students, in turn, learn to listen, search and argue the most rational way of negotiation, which allows you to develop communication skills, trains endurance, tact, sympathy and other indicators of communication culture and business ethics.

In confirmation of the effectiveness of the above is the fact that the most in demand will be those professionals who are able to learn throughout life, set goals and achieve them, think critically, work in a team and more. Therefore, it is important to reorient the training of future teachers of education to the role of researcher, agent of change, gaining effective means of organizing the educational process in the interests of students, as discussed in the Concept "New Ukrainian School" (2016) [12; 13].

The formula of the new school consists of nine key components, one of the components of which is based on the partnership between the student, the teacher and the parents. It should be noted that the pedagogy of partnership is based on communication, interaction and cooperation between teacher, student and parents [13].

Therefore, it is important to train future teachers of the new Ukrainian school on the basis of interaction, including facilitation, which is a process of helping and supporting the individual in various situations of interpersonal interaction, as a result of which under certain conditions is conscious, intensive and productive self-development [9, p. 107].

The Concept of the New Ukrainian School states that the educational process in a general secondary education institution should be based on the principles of partnership pedagogy, which is based on the main trends of humanistic pedagogy and creative approach to personal development [13]. V. Mysan in his study argues that "a truly democratic way of cooperation between teacher and child, which does not rule out differences in their life experiences, knowledge, but provides unconditional equality in the right to respect, trust, friendliness and mutual demands" [5]. The child, his interests, abilities, talents and abilities should be the focus of all participants in the educational process: teachers, students, parents. O. Vyshnevsky is convinced that the teacher should be a friend, and parents - involved in building the educational trajectory of the student [15]. Relationships should be built on the principles of equality, dialogue, self-improvement, acceptance. According to O. Plakhotnyk, the teacher's activity should be aimed at interaction, mutual understanding, support, awareness of personal responsibility for the student's learning outcomes. The teacher, who is assigned the role of facilitator and tutor, should be not just a subject specialist, but a professional "who knows how to work with the processes of education and development, organize educational 
work to solve creative problems, show initiative, independence" [8]. The main task of pedagogical universities today is to train "agents of change" in education. In order for the new generation of specialists to appear in the school in 2022, as provided by the Concept, it is necessary to start training them. And in 10 years we will have "a solid army of facilitators, tutors, moderators, coaches" [5].

The need for pedagogical research in terms of training future teachers of the new Ukrainian school on the basis of facilitation interaction is due to a number of factors: first, in the process of facilitation interaction new relationships are formed between actors (teachers, students and parents), which allows to realize new social roles different types of information; secondly, the unity and coherence of the system of educational influences of adults on the child is ensured; thirdly, they are made in understanding the educational situation, determining the degree of solidarity in solving problems of education and upbringing; fourthly, the formation of ties of mutual understanding and mutual respect between students, parents, teachers and their acquisition of social experience, mastering the cultural values of the native school, acquired by the previous self-favorably, prior to the prior provision of personal interests. which encourages students to combat immoral offenses, spirituality, anticivic activities.

It should be noted that the organization of the educational process of the student of the new Ukrainian school has certain specific features: increasing independence, which leads to an increase in the level of self-management influences, necessitates the introduction of selfcontrol and reflection on educational activities; the selectivity of learning interests and needs of students requires the use of a differentiated approach in the learning process and reliance on internal motivation to learn; the tendency to comparisons, generalizations, systematization, which indicates the growing role of theoretical thinking of students, necessitates the introduction of a deductive method of presenting educational information and methods of forming critical thinking.

Based on the analysis of the scientific literature $[2 ; 3 ; 6 ; 11]$ proved the effectiveness of the educational process and the effectiveness of educational activities of school students, based primarily on the individual characteristics of students, and the organization of their educational activities, in terms of outlined features and modernization in modern conditions, is considered as a basis for educational trajectory of students.

\section{Conclusions}

Thus, the analysis of research results on teacher training in Ukraine shows that this process is the result of students' professional orientations and motives, future teachers master 
the system of knowledge about the modern lesson, skills development, development of necessary facilitation qualities for effective educational process in New Ukrainian School. It should be noted that the numerous and significant in theoretical and methodological results of our analyzed studies provide grounds to reveal the benefits of interaction, including facilitation, in the educational process.

\section{References:}

1. Hall G. E. Three Principal Styles of Facilitating School Improvement, in Making Our Schools More Effective: proceedings of three stale conferences, Texas. USA. School Effectiveness and School Improvement, 1984. № 2(4). P. 286-304.

2. Kondrashikhina OO Formation of ability to facilitation influences at future practical psychologists: dis. ... cand. psychol. Science: 19.00.07. K., 2014. 182 p.

3. Kravchynska T. Pedagogy of partnership - basic ideas, principles and essence. URL: https://www.google.com/search?q= -108 .

4. Martynova A. V. Facilitation as a technology of organizational development and change. Organizational psychology. 2011.Vol. 1.No. 2.P. 53-91.

5. Mysan V. Will the school "Agent of Change" receive in the near future? URL: http://education-ua.org/ua/articles/799/

6. New Ukrainian school: a guide for teachers. For the general ed. N.M. Bibik. K: Litera LTD, 2018. 160 p.

7. Pavlenko VV Resource and style set of methods for managing stressful situations. Science and education. 2004. № 6-7. Pp. 202-205.

8. Plakhotnyk O. Implementation of ideas of pedagogy of cooperation in the educational process. URL: https://www.google.com/search?q=/

9. Prokopenko I. A. Substantiation of the system of preparation of future teachers for facilitation interaction with students of general secondary education institutions. Theory and methods of teaching and education. 2019. № 47. S. 101-112. DOI: 10.34142 / 23128046.2019.47.09

10. Prokopeno I. A. The facilitation style of interaction as productive teaching style. Středoevropský věstník pro vědu a výzkum. Praha: Publishing house Education and Science, 2020. Vol. 4(65) P. 36-42.

11. Smirnova O. Organization of the educational process on the basis of partnership pedagogy in the implementation of the Concept of the new Ukrainian school. URL: https://www.google.com/search?q=.

12. The concept of "New school: a space of educational opportunities." 
URL:http://mon.gov.ua/\%D0\%9D\%D0\%BE\%D0\%B2\%D0\%B8\%D0\%BD\%D0\%B8\%20 20 16/08/21 / 2016-08-17-3-.pdf

13. The concept of the New Ukrainian School. URL: https: www.kmu. gov.ua/storage/app/media/reforms/ukrainska-shkola-compressed.pdf.

14. Van Maurik J. Facilitating excellence; styles and processes of facilitatiom. Leadership and Organizational Developmental Journal. 1994. №15 (8). P.30-34.

15. Vyshnevsky O. Theoretical foundations of modern Ukrainian pedagogy: A guide for students of higher educational institutions. Drogobich: Kolo, 2006. 326 p. 